https://nv.nltu.edu.ua

https://doi.org/10.36930/40310122

$@ \bowtie$ Correspondence author

Article received 22.01.2021 p.

Article accepted 04.02.2021 p.

V. M. Teslyuk

UDC 004.[021+942]

В. М. Теслюк, А. Г. Казарян, І. Я. Казимира

Національний університет "Львівська політехніка", м. Львів, Україна

\title{
ОПРАЦЮВАННЯ ДАНИХ У СИСТЕМАХ "РОЗУМНОГО" БУДИНКУ З ВИКОРИСТАННЯМ МОДЕЛЕЙ НА ПІДСТАВІ МЕРЕЖ ПЕТРІ
}

Проаналізовано особливості використання ієрархічних мереж Петрі для розроблення масштабованої та відмовостійкої моделі опрацювання даних у системах "розумного" будинку. Застосовано підхід, який забезпечує підвищену надійність функціонування систем та їхню швидкість роботи під час різкого збільшення обсягу інформації, що надходить від давачів, яку потрібно опрацювати згідно з реалізованою внутрішньою логікою. Розроблено підхід та приклади мереж Петрі, що створюють ієрархічну логіку функціонування підсистем "розумного" будинку. З'ясовано, що поділ функціоналу системи на окремі модулі дає змогу реалізувати кожну окрему логічну функцію у вигляді закритої системи 3 чітко визначеним форматом вхідних і вихідних даних. Вхідні дані подано змінами показників давачів, що розташовані у будинку. Водночас вихідні дані представлені чітко визначеним результатом роботи підсистеми, що відповідає конкретній функції всієї системи у вигляді розрахованих нових параметрів її налаштувань і побутових приладів. Завдяки специфіці функціонування підсистем "розумного" будинку з чітко визначеними правилами зміни станів налаштувань системи та правил реагування нею на виниклі події, всі підсистеми можна реалізувати у вигляді мереж Петрі, ієрархічно розташованими у структурі внутрішньої логіки системи "розумного будинку". Події, що виникають у системі й зберігають різний набір даних залежно від подій, що виникли, представлені окремими типами (кольорами) маркерів мереж Петрі. Отже, всі підсистеми реалізують кольорову ієрархічну мережу Петрі. Реалізовано логіку функціонування підсистем "розумного" будинку, робота яких базується на підставі теорії мереж Петрі, що дало змогу розробити мікросервісну архітектуру комплексної системи з гнучким механізмом автоматизованого балансування обчислювального навантаження на окремі функції та можливістю швидшого відновлення повноцінної роботи системи після низки аварійних ситуацій порівняно з монолітною архітектурою комп'ютерних систем, що є поширеним підходом на сьогодні під час розроблення систем цього типу.

Ключові слова: архітектура комп'ютерних систем; автоматизація управління процесами; мікросервіси; оптимізація роботи комп'ютерних систем.

\section{Вступ}

На сьогодні системи "розумного" будинку [2, 4] стикаються з проблемами оптимізації обчислювальних ресурсів у періоди пікових навантажень, що в цій сфері застосування $є$ непередбачуваними, а також із можливістю швидкого автоматичного відновлення роботи системи після збоїв, спричиненими аварійними ситуаціями. Подання системи "розумного" будинку у вигляді багатошарової архітектури програмних модулів незалежних підсистем дає змогу запускати та зупиняти роботу окремих екземплярів програмних модулів залежно від обчислювальних потреб та швидко перезапускати окремі підсистеми після збою в їхній роботі на противагу довгому та високозатратному процесу перезапуску системи загалом. Цей тип складних систем з паралельно розподіленими процесами, функціонування яких добре моделювати за допомогою ієрархічних мереж Петрі, що є розширенням їхнього звичайного подання, у яких переходи є повноцінними мережами Петрі.

Об'єкт дослідження - процес функціонування системи "розумного" будинку.

Предмет дослідження - моделі на підставі мереж Петрі для дослідження динаміки функціонування системи "розумного" будинку.

Мета роботи - опрацювання даних у системах "розумного" будинку з використанням моделей на підставі мереж Петрі, що забезпечить можливість дослідження показників швидкодії та відмовостійкості роботи ієрархічної системи.

Для досягнення зазначеної мети визначено такі основні завдання дослідження: розглянути наявні підходи до програмної реалізації систем "розумного" будинку; розробити моделі на підставі мереж Петрі для дослідження функцій системи "розумного" будинку; проаналізувати результати ефективності використання кольорової ієрархічної мережі Петрі для роботи системи "розумного" будинку.

\section{Інформація про авторів:}

Теслюк Василь Миколайович, д-р техн. наук, професор, завідувач кафедри автоматизованих систем управління. Email: vasyl.m.teslyuk@lpnu.ua; https://orcid.org/0000-0002-5974-9310

Казарян Артем Геннадійович, аспірант, кафедра автоматизованих систем управління. Email: artem.kazarian@gmail.com Казимира Ірина Ярославівна, канд. техн. наук, доцент, кафедра екологічної безпеки та природоохоронної діяльності. Email: iryna.y.kazymyra@lpnu.ua; https://orcid.org/0000-0003-1597-5647

Цитування за ДСтУ: Теслюк В. М., Казарян А. Г., Казимира І. Я. Опрацювання даних у системах "розумного" будинку з використанням моделей на підставі мереж Петрі. Науковий вісник НлтУ України. 2021, т. 31, № 1. С. 131-136.

Citation APA: Teslyuk, V. M., Kazarian, A. H., \& Kazimira, I. Ya. (2021). Data processing in smart home systems using models based on Petri network theory. Scientific Bulletin of UNFU, 31(1), 131-136. https://doi.org/10.36930/40310122 
Наукова новизна отриманих результатів дослідження - вперше розроблено моделі з використанням ієрархічної мережі Петрі, що забезпечило покращення показників швидкодії та відмовостійкості роботи системи порівняно $з$ "класичним" монолітним архітектурним підходом.

Практична значущість результатів дослідження алгоритми та отримані результати дослідження показників швидкодії та відмовостійкості роботи систем "розумного" будинку можна використовувати для дослідження показників швидкодії та відмовостійкості роботи ієрархічної системи.

Аналіз останніх досліджень та публікацій. Проаналізовані наукові праці, що розглядають використання мереж Петрі для моделювання процесів роботи систем "розумного" будинку, здебільшого описують застосування кольорових мереж Петрі, що є добрим прикладом візуалізації процесів, пов'язаних $з$ опрацюванням різних типів подій, поданих відповідними кольорами, що виникають у системі. Наприклад, у роботі [7] описано загальну продуктивність алгоритмів систем "розумного" будинку та модель його системи, робота якого базується на підставі кольорових мереж Петрі, які дають змогу досліджувати динаміку системи загалом, а також внутрішню взаємодію іiї основних структурно-функціональних підсистем на рівні системного проєктування. Багато науковців [3, 5] кольорові мережі Петрі пропонують застосовувати у системах "розумного" будинку для моніторингу процесу ін'єкції для пацієнтів, що потребують лікування у домашніх умовах. У наведеному прикладі [9] мережа Петрі ефективно справляється 3 поставленим завданням запобігати небезпечним ситуаціям завдяки чітко визначеному набору конкретних дій, що характеризують сферу медицини. Інша наукова праця [1] описує розробку "розумної" енергозберігаючої системи для інтеграції нових передових технологій та звичайних систем кондиціонування повітря для досягнення комфортного середовища, оптимальної енергоефективності та прибутковості. У цій роботі реалізовано триступеневу інтелектуальну систему управління, яка дає змогу контролювати кімнатну температуру, відповідно до уподобань користувача. Розглянуті наукові праці описують процеси верхнього шару систем сфери "розумного" будинку, узагальнюючи функції програмних продуктів, коли реально створені системи $\epsilon$ сукупністю багатьох підсистем 3 чітко визначеною структурою, що можна описати 3 використанням ієрархічних мереж Петрі. Цей підхід $\epsilon$ зручним у процесі створення мікросервісної програмної архітектури для розроблення масштабованої та відмовостійкої розподіленої системи "розумного" будинку.

\section{Результати дослідження та їх обговорення}

Розроблення моделі опрацювання даних у системах "розумного" будинку з використанням ієрархічних мереж Петрі. Для реалізації ідеї використання окремих програмних модулів системи "розумного" будинку та ефективного виділення обчислювальних ресурсів для кожного 3 них окремо, запропоновано створювати нові або переробити вже наявні структури програмного забезпечення керуючись принципами мікросервісної архітектури [6]. На відміну від монолітної архітектури [8], у якій вся програмна логіка системи міститься в одній кодовій базі, а мікросервісна архітектура будується як сукупність невеличких програмних модулів, кожен 3 яких працює у своєму власному процесі та обмінюється інформацією 3 рештою, використовуючи прості та швидкі протоколи передачі даних. Цей підхід забезпечить логічне відокремлення програмних модулів системи, доступні обчислювальні ресурси, які будуть регулюватися залежно від навантаження кожного окремо. Моделювання комплексної системи "розумного" будинку, що передбачає функції автоматизованого розрахунку оптимальних параметрів побутових приладів, приладів освітлення, системи безпеки та клімат-контролю для забезпечення комфортного проживання мешканців, проведено з використанням ієрархічних мереж Петрі.

Для імітації роботи системи "розумного" будинку створено основну мережу Петрі вищого рівня для імітації роботи системи загалом, а також три деталізовані дочірні мережі Петрі, які забезпечують моделювання роботи підсистем "розумного" будинку для керування освітленням, керування температурним режимом та функції системи безпеки.

Події у приміщеннях будинку, які виникають під час зміни значень від давачів, розташованих у будинку, подано у вигляді переходів мереж Петрі. Опис позицій та переходів основної мережі Петрі, використаної для моделювання процесів роботи системи "розумного" будинку, наведено у табл. 1.

Табл. 1. Опис позицій основної мережі Петрі системи "розумного" будинку

\begin{tabular}{|c|l|c|l|}
\hline $\begin{array}{c}\text { По- } \\
\text { зи- } \\
\text { ція }\end{array}$ & \multicolumn{1}{|c|}{ Опис позиції } & $\begin{array}{c}\text { Пе- } \\
\text { ре- } \\
\text { хід }\end{array}$ & \multicolumn{1}{|c|}{ Опис переходу } \\
\hline P0 & Стан вимкненої системи & T1 & Увімкнення системи \\
\hline P1 & Стан увімкненої системи & $\mathbf{T 2}$ & Вимкнення системи \\
\hline P2 & Зафіксована давачем подія & $\mathbf{T 3}$ & Спрацювання давача \\
\hline P3 & $\begin{array}{l}\text { Стан готовності опрацю- } \\
\text { вання подій }\end{array}$ & $\mathbf{T 4}$ & $\begin{array}{l}\text { Запуск оброблення } \\
\text { події }\end{array}$ \\
\hline $\mathbf{P 4}$ & $\begin{array}{l}\text { Стан налаштувань темпера- } \\
\text { тури }\end{array}$ & $\mathbf{T 5}$ & $\begin{array}{l}\text { Робота клімат-кон- } \\
\text { тролю }\end{array}$ \\
\hline P5 & $\begin{array}{l}\text { Стан налаштувань освіт- } \\
\text { лення }\end{array}$ & $\mathbf{T 6}$ & $\begin{array}{l}\text { Робота контролю ос- } \\
\text { вітлення }\end{array}$ \\
\hline P6 & Стан налаштувань безпеки & $\mathbf{T 7}$ & $\begin{array}{l}\text { Робота контролю } \\
\text { безпеки }\end{array}$ \\
\hline P7 & Стан нового стану системи & $\mathbf{T 8}$ & $\begin{array}{l}\text { Генерування нового } \\
\text { стану }\end{array}$ \\
\hline
\end{tabular}

Основну мережу Петрі, розроблену для моделювання процесів роботи системи "розумного" будинку та взаємодії їі підсистем, подано на рис. 1.

Підсистема керування освітленням виконує функції увімкнення та вимкнення освітлювальних приладів приміщення залежно від перебування у відповідних кімнатах людей, враховуючи режими налаштувань, увімкнені користувачами особисто. Мережу Петрі, розроблену для моделювання процесів роботи підсистеми керування освітленням у системі "розумного" будинку, подано на рис. 2.

Події, які впливають на роботу підсистеми керування освітленням "розумного" будинку, подано у вигляді переходів мереж Петрі. Опис позицій та переходів мережі Петрі підсистеми керування освітленням системи "розумного" будинку наведено у табл. 2. 


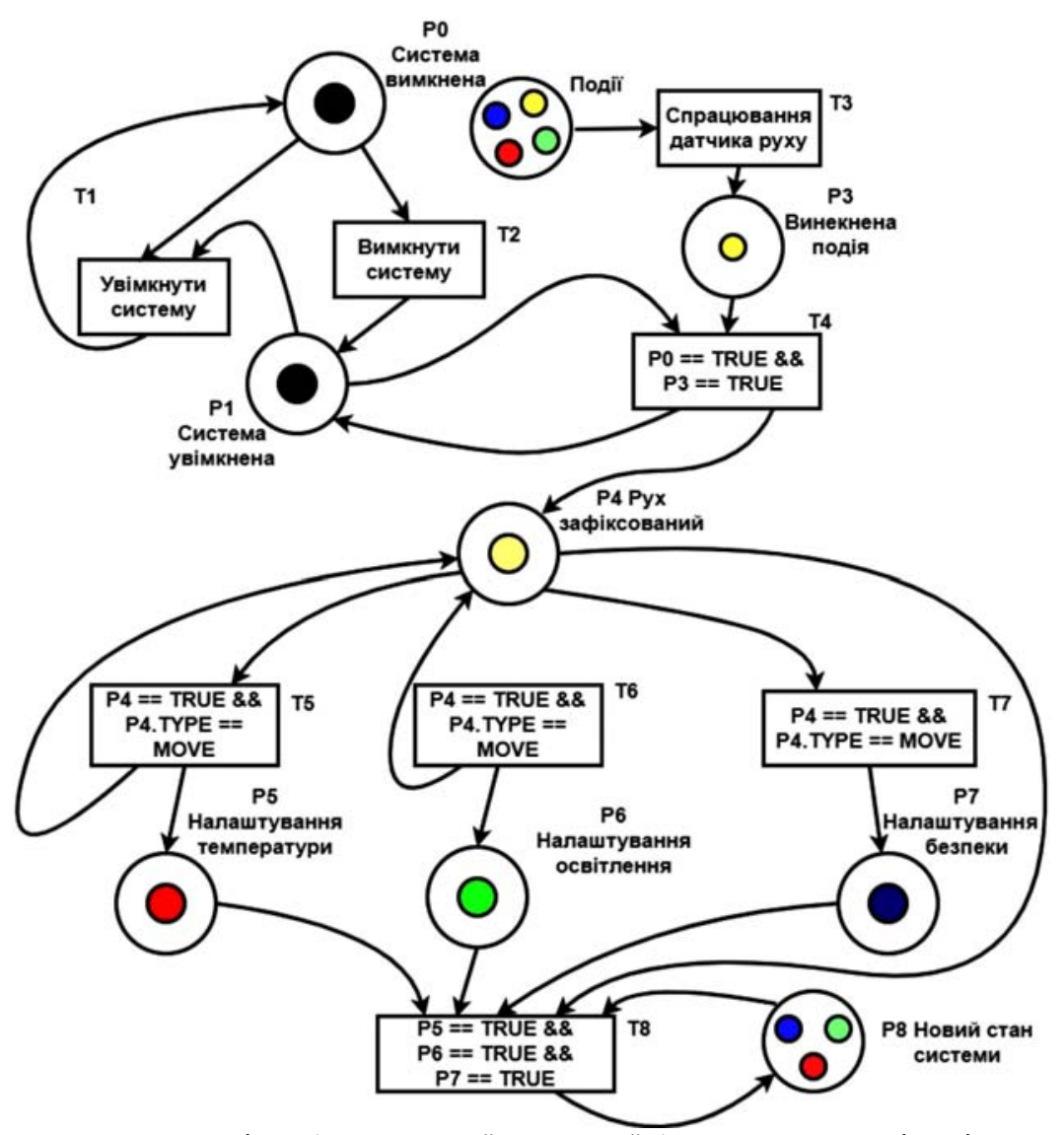

Рис. 1. Мережа Петрі: моделювання процесів роботи системи "розумного" будинку та взаємодії їі підсистем

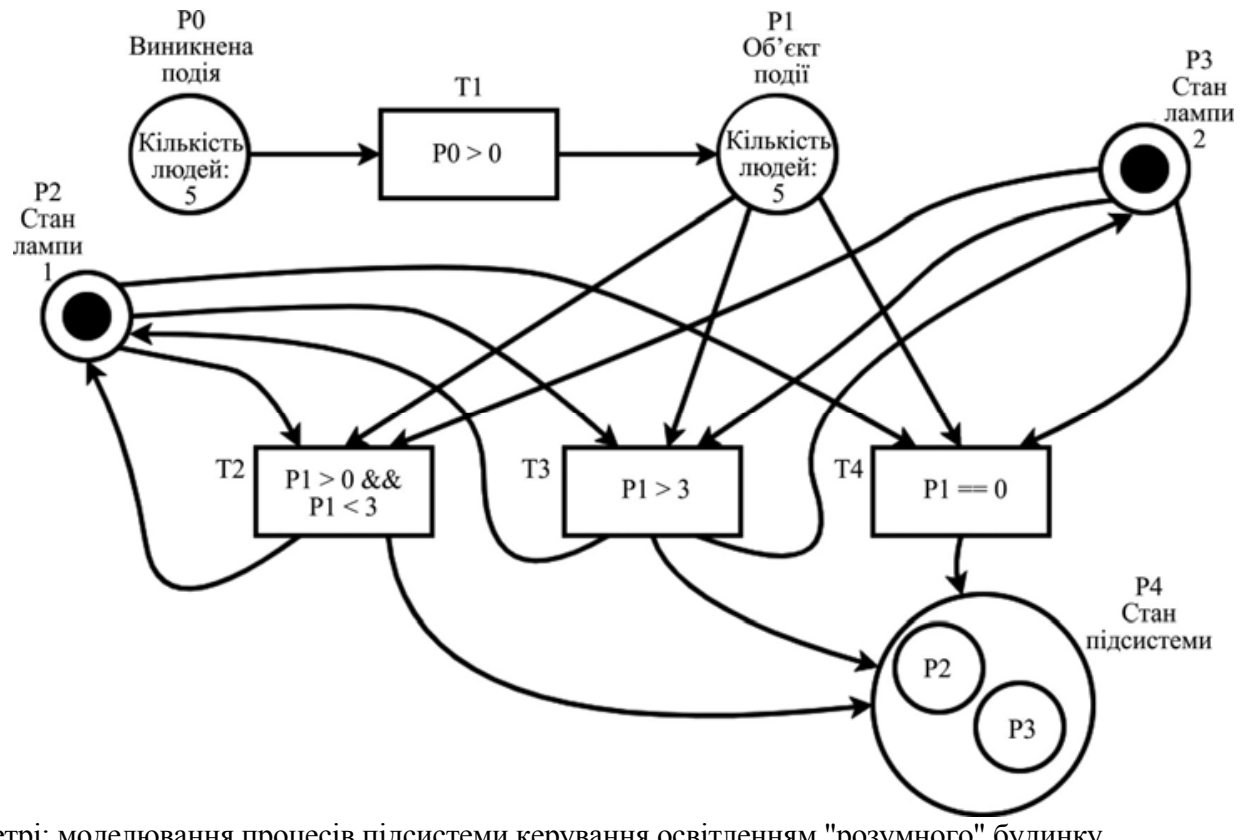

Рис. 2. Мережа Петрі: моделювання процесів підсистеми керування освітленням "розумного" будинку

Табл. 2. Опис позицій мережі Петрі підсистеми керування освітленням

\begin{tabular}{|c|l|c|c|}
\hline \multicolumn{1}{|c|}{ Позиція } & \multicolumn{1}{|c|}{ Опис позиції } & Перехід & Опис переходу \\
\hline $\mathbf{P 0}$ & Зафіксована давачем подія & $\mathbf{T 1}$ & Запуск опрацювання події \\
\hline $\mathbf{P 1}$ & Об'єкт події для оброблення & $\mathbf{T 2}$ & Увімкнення лампи 1 \\
\hline $\mathbf{P 2}$ & Стан увімкненої лампи 1 & $\mathbf{T 3}$ & Увімкнення лампи 1 та лампи 2 \\
\hline $\mathbf{P 3}$ & Стан увімкненої лампи 2 & $\mathbf{T 4}$ & Вимкнення всіх ламп освітленням \\
\hline $\mathbf{P 4}$ & Новий стан освітлення & & \\
\hline
\end{tabular}

Табл. 3. Опис позицій мережі Петрі підсистеми керування системою безпеки "розумного" будинку

\begin{tabular}{|c|l|c|c|}
\hline Позиція & \multicolumn{1}{|c|}{ Опис позиції } & Перехід & Опис переходу \\
\hline $\mathbf{P 0}$ & Зафіксована давачем подія & $\mathbf{T 1}$ & Запуск опрацювання події \\
\hline $\mathbf{P 1}$ & Об'єкт події для оброблення & $\mathbf{T 2}$ & Увімкнення звукової сирени \\
\hline $\mathbf{P 2}$ & Стан увімкненої сирени & $\mathbf{T 3}$ & Вимкнення звукової сирени \\
\hline $\mathbf{P 3}$ & Новий стан системи безпеки & $\mathbf{T 4}$ & \\
\hline
\end{tabular}


Підсистема керування системою безпеки виконує функції сповіщення користувачів системи у разі їхньої відсутності у будинку про відкриття вікон, відкриття дверей та рух всередині будинку зафіксований за допомогою давачів руху встановлених у помешканні. Мережу Петрі, розроблену для моделювання процесів роботи підсистеми керування системою безпеки у системі "розумного" будинку, зображено на рис. 3.

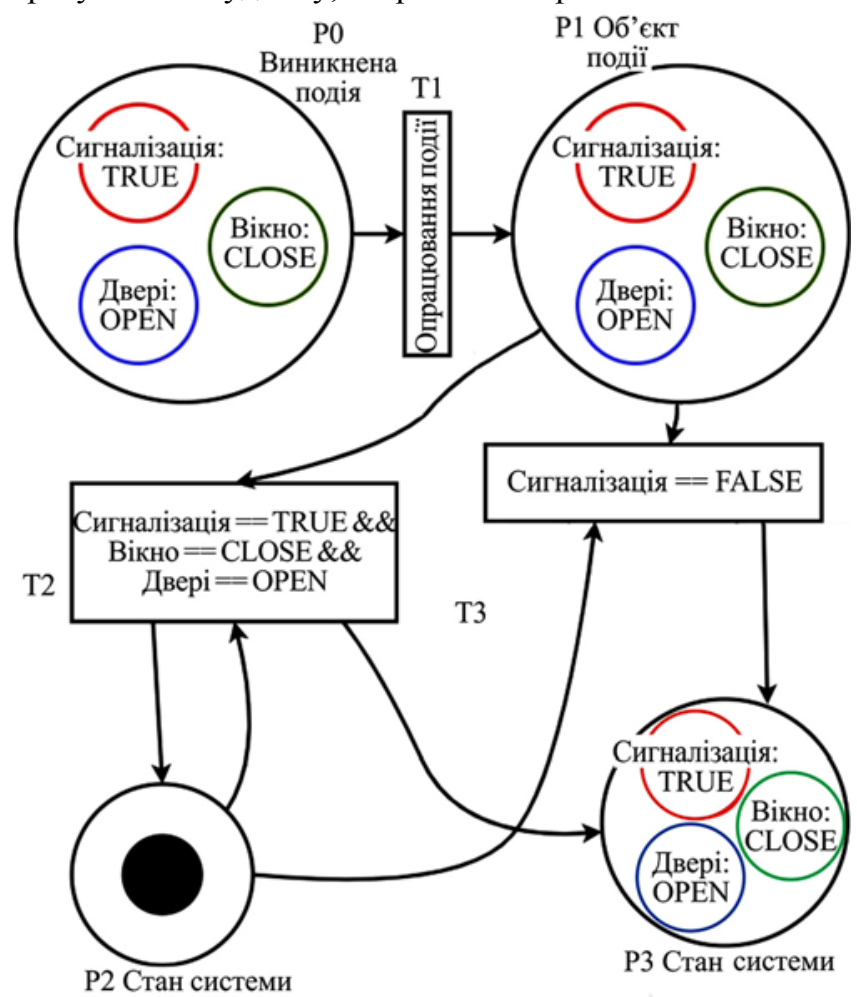

Рис. 3. Мережа Петрі: моделювання процесів підсистеми керування системою безпеки "розумного" будинку

Події, які впливають на роботу підсистеми керування системою безпеки "розумного" будинку, подано у вигляді переходів мереж Петрі. Опис позицій та переходів мережі Петрі, використаної для моделювання процесів роботи підсистеми керування системою безпеки, наведено у табл. 3 .

Кожна окрема підсистема "розумного" будинку, логіка якої створена на підставі роботи мережі Петрі, за допомогою дій системи (зміни режимів роботи побутових приладів) унаслідок спрацювання переходів та зміни станів системи (налаштувань оптимальної температури, налаштувань освітлення, тощо) відповідно до станів міток мережі Петрі реалізовується у вигляді мікросервісу будь-якого провайдера хмарних обчислень, що надає послуги "безсерверних" функцій.

Поділ функціоналу та чітке розмежування логіки системи за допомогою окремих дочірніх мереж Петрі, реалізованих окремими мікросервісами, дає змогу ефективно оптимізувати виділення обчислювальних ресурсів під час роботи системи, враховуючи ситуації нерівномірного навантаження на окремі функції системи, наприклад, коли під час різкого збільшення кількості людей у великому будинку (лікарня, навчальний заклад тощо) істотно збільшується кількість запитів на екземпляри мікросервісів 3 логікою мереж Петрі, що відповідають за керування освітлювальними приладами, тоді як навантаження на мережі Петрі, які стосуються зміни налаштувань температури, на зазнають істотних змін.
Алгоритм створення та видалення окремих екземплярів мікросервісів з логікою дочірніх мереж Петрі для реалізації автоматизованого масштабування системи відповідно до динамічних змін навантажень та механізму швидкого відновлення повноцінної роботи усіх функцій системи після появи критичних ситуацій зображено на рис. 4.

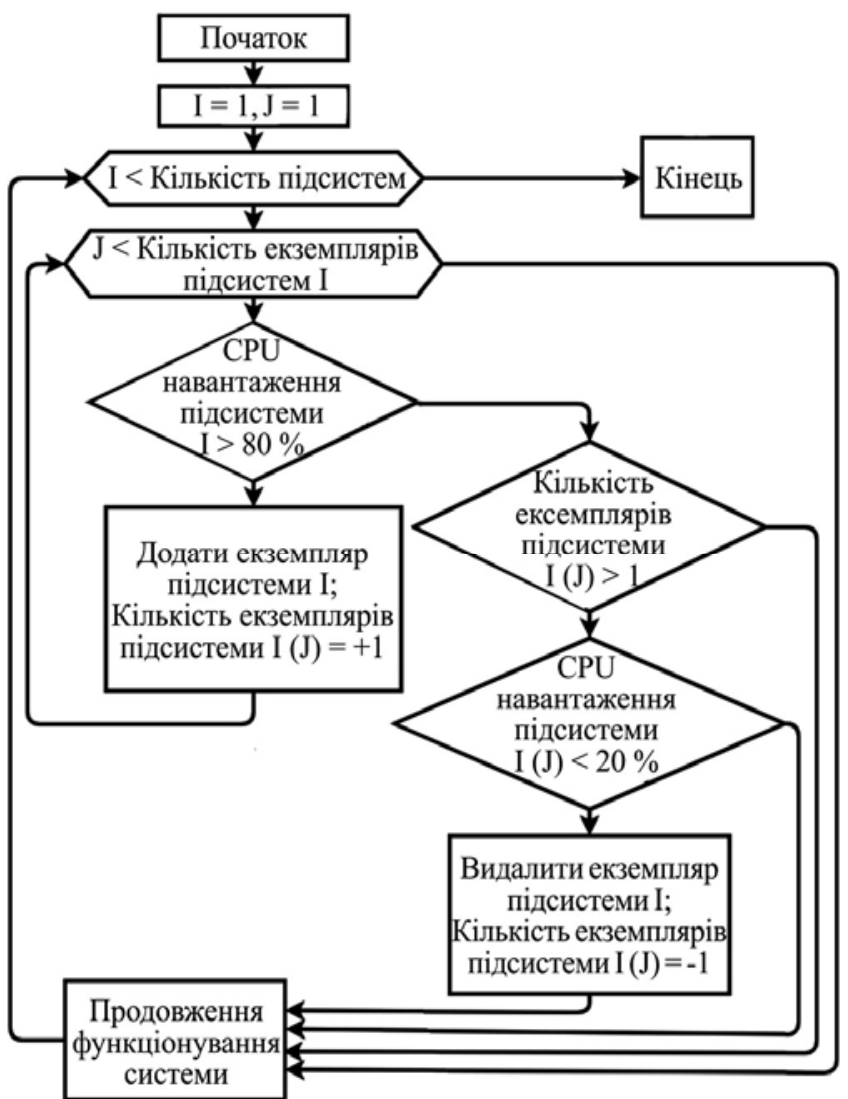

Рис. 4. Алгоритм створення та видалення окремих екземплярів мікросервісів

Обговорення результатів дослідження. Використання мікросервісної архітектури та "безсерверних" принципів побудови системи "розумного" будинку дає змогу уникнути потреби перезапускати всю систему загалом після збоїв у роботі. Критична помилка, що виникла в окремому програмному модулі, відповідає за одну функцію роботи системи, реалізована у вигляді дочірньої мережі Петрі, призводить до перезапуску цього конкретного модуля. Таке рішення зменшує час, що проходить до повноцінного відновлення роботи системи після аварійних ситуацій. Також використаний підхід забезпечує безперервну активність роботи решти модулів системи, що не піддались впливу критичної ситуації для забезпечення безперервного надання решти функціоналу користувачам. Для проведення дослідження 3 ефективності запропонованого підходу в роботі розробленої у попередніх дослідженнях системи "розумного" будинку монолітної архітектури та покращеної архітектури системи, були створені штучні умови виникнення критичних ситуацій, що призводять до аварійних перезапусків системи. На рис. 5 зображено порівняння періодів роботи та простою системи загалом за використання монолітної архітектури та окремих модулів за використання мікросервісної архітектури на базі ієрархічних мереж Петрі. 


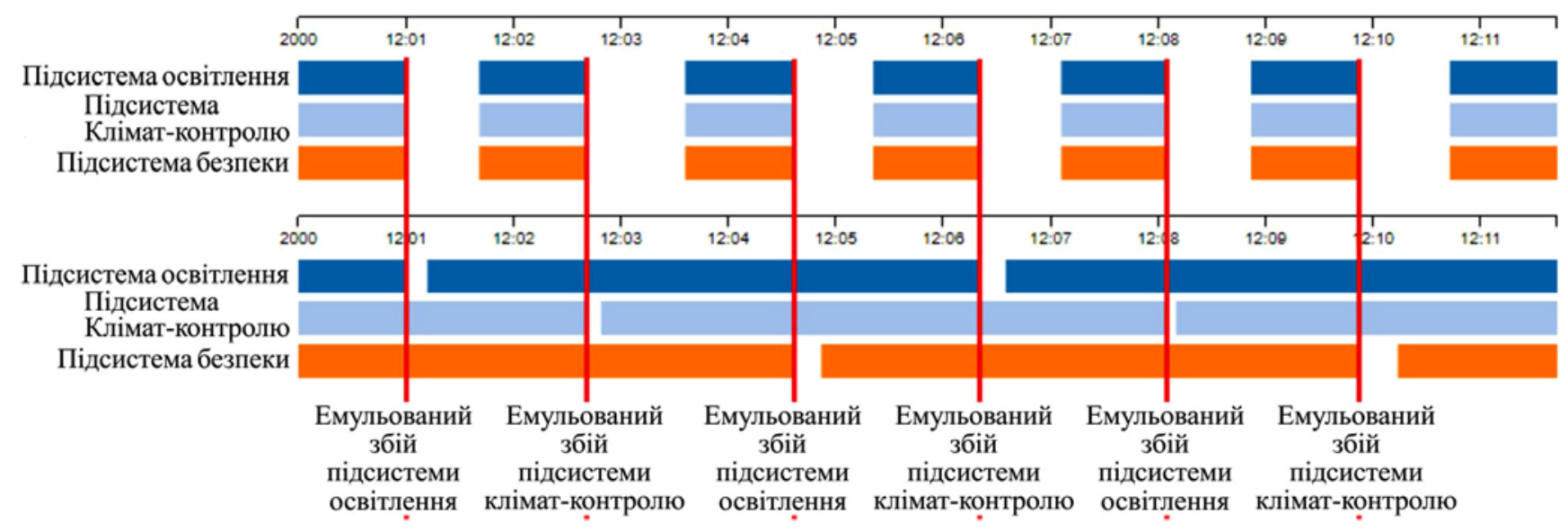

Рис. 5. Порівняння періодів роботи та простою системи

Аналіз результатів дослідження показав, що після виникнення критичних ситуацій у роботі монолітної архітектури системи "розумного" будинку час перезапуску всієї системи змінювався у межах від 41 до 55 секунд. Емуляція виникнення аварійних ситуацій у роботі системи мікросервісної архітектури призводила до перезапуску окремих модулів системи створених на підставі мереж Петрі, що робило тимчасово недоступними окремі функції системи впродовж таких проміжків часу: керування освітленням - 12-14 с, керування температурним режимом - 8-11 с, керування системою безпеки - 16-22 с. Водночас інші функції, що не були пов'язані логічно з модулем, у якого трапилась аварійна ситуація, продовжували справно працювати.

\section{Висновки}

Обгрунтовано ефективність використання мікросервісної архітектури програмного забезпечення систем "розумного" будинку для підвищення показників надійності та швидкодії системи, використовуючи моделювання за допомогою ієрархічних мереж Петрі. Здійснено реструктуризацію монолітної архітектури системи "розумного" будинку з використанням мікросервісного підходу, що дало змогу зменшити час самостійного відновлення роботи системи після виниклих аварійних ситуацій на 50 \%. Проаналізовано, що ієрархічні мережі Петрі є потужним інструментом, які дають змогу швидко структуризувати функціонал складних комплексних систем на менші логічно відокремлені підсистеми, що реалізуються у вигляді окремих дочірніх мереж Петрі з чітко визначеними правилами та умовами зміни станів налаштувань системи "розумного" будинку. Реалізація окремих підсистем у вигляді мереж Петрі дає змогу полегшити процес масштабування завдяки легкій можливості додавання, видалення та зміни функціоналу системи способом інтеграції в ієрархічну мережу Петрі вищого рівня системи "розумного" будинку.

\section{References}

1. Bouazza, Kheir Eddine \& Deabes, Wael. (2019). Smart Petri Nets Temperature Control Framework for Reducing Building Energy Consumption. Sensors. $\quad 19, \quad 24-41$. https://doi.org/10.3390/s19112441

2. Kazarian, A., Teslyuk, V., Tsmots, I., \& Mashevska, M. (2017). Units and structure of automated "smart" house control system using machine learning algorithms, 364-366. https://doi.org/10.1109/CADSM.2017.7916151

3. Majma, Negar \& Babamir, Seyed Morteza. (2014). Specification and Verification of Medical Monitoring System Using Petri-nets. Journal of Medical Signals \& Sensors, 4, 181-193. https://doi.org/10.4103/2228-7477.137769

4. Molnar, E., Molnar, R., Kryvinska, N., \& Greguš, M. (2014). Web intelligence in practice. Journal of Service Science Research, 6, 149-172. https://doi.org/10.1007/s12927-014-0006-4

5. Ouzayd, F., Mansouri, Hajar, Tamir, Manal, Chiheb, Raddouane \& Rhouma, Zied. (2018). Monitoring Vaccine Cold Chain Model with Coloured Petri Net. International Journal of Advanced Computer Science and Applications, https://doi.org/10.14569/IJACSA.2018.090556

6. Soldani, J., Tamburri, D., \& Heuvel, Willem-Jan. (2018). The Pains and Gains of Microservices: A Systematic Grey Literature Review. Journal of Systems and Software, 146. https://doi.org/10.1016/j.jss.2018.09.082

7. Teslyuk, V., Beregovskyi, V., \& Pukach, A. I. (2013). Development of smart house system model based on colored Petri nets, 205-208.

8. Villamizar, M., Garcés, O., Castro, H., Verano Merino, M., Salamanca, L., Casallas, R., \& Gil, S. (2015). Evaluating the monolithic and the microservice architecture pattern to deploy web applications in the cloud. https://doi.org/10.1109/ColumbianCC.2015.7333476

9. Xin-Liang Wang, \& Qing-Gai Huang. (2018). Infusion Monitoring Communication Model of Smart Home Based on Coloured Petri Net. Int $J$ Bioautomation, 22(3), 239-252. https://doi.org/10.7546/ijba.2018.22.3.239-252

V. M. Teslyuk, A. H. Kazarian, I. Ya. Kazimira

Lviv Polytechnic National University, Lviv, Ukraine

\section{DATA PROCESSING IN SMART HOME SYSTEMS USING MODELS BASED ON PETRI NETWORK THEORY}

The article describes the usage of hierarchical Petri networks for development of a scalable and fault-tolerant data processing model in smart home systems. The proposed approach provides increased reliability of the systems and their work speed during a sharp increase in the amount of information coming from the sensors, which must be processed according to the implemented internal logic. The presented work describes the developed approach and examples of Petri nets, which create a hierarchical logic of functioning of subsystems of a smart home. Dividing the functionality of the system into separate modules allows implementing each individual logical function in the form of a closed system with a clearly defined format of input and output data. The input data are repre- 
sented by changes in the indicators of sensors located in the house, in turn the output data is a clearly defined result of the subsystem, whose operation corresponds to a specific function of the system in the form of calculated new parameters of system settings and appliances. Due to the specifics of the operation of smart home systems with clearly defined rules for changing system settings and system response to the occurrence of events, all subsystems can be implemented in the form of Petri nets hierarchically located in the internal logic of the smart home system. Events that occur in the system and store a different set of data depending on the events are presented by separate types (colours) of Petri nets markers. Thus, all subsystems implement a colour hierarchical Petri net. Implementation of subsystems of smart home based on Petri nets allowed developing a microservice architecture of a complex system with a flexible mechanism of automated balancing of computing load on individual functions and the ability to quickly restore full operation of the system after emergencies compared to the computer, which is a common approach today in the development of systems of this type.

Keywords: computer systems architecture; process control automation; microservices; computer systems optimization. 